\title{
Pursuing diversified universities
}

The Australian government's proposed university policy increases competition and market forces in the sector, while raising justified concerns about independence and infrastructure. But the goal of diversifying higher education is appropriate.

$\square$ stablishing suitable levels of access to higher education and funding academic research infrastructure are challenges that face many countries. Australia has long been in the vanguard of providing publicly funded student loans, while funds for its laboratories are all too scarce. So a significant change in its approach to higher education is worth watching. The Australian federal government has now unveiled its plan for the most significant reform of the nation's universities in more than a decade. The blueprint seems to reflect the government's philosophy of 'the user pays' and the promotion of élite institutions. The good news is that the universities will probably receive more money. But there are concerns about growing student debt and potential government influence over university curricula.

The blueprint allows universities to ratchet up student fees and increase the proportion of full-fee-paying students. Currently, universities enroll students through two routes. For governmentsubsidized places, students contribute a proportion of the costs, payment of which can be delayed until they have graduated and reach a threshold salary in the workplace. Alternatively, university places can be filled with full-fee-paying students, who, in some instances, can gain entry on lower academic scores than those competing for subsidized places. Under the new scheme, the proportion of university places available for full-fee-paying students will rise from $25 \%$ to $50 \%$. The fee contributions demanded of government-subsidized students can be increased to $30 \%$ above current levels.

It is not surprising that many university chiefs have embraced this partial fee deregulation, as universities are parched from years of declining government funds. Alarmingly, the modest additional government contribution to courses - A \$404 million (US\$267 million) over four years from 2005 - has strings attached. The universities must comply with reforms including individual workplace agree- ments, restrictions on industrial action and the abolition of compulsory student unions. Furthermore, the government will negotiate contributions to each individual institution, and it is unclear whether it will play a controlling or a consultative role in determining the type of courses and number of places offered by different universities.

The reform is a realization of the government's ambition to propel a few Australian universities into the upper echelons of global tertiary institutions, attracting élite academics and conducting world-class teaching and research. Beneath these will be a spectrum of less prestigious, more vocationally oriented universities, which are likely to be more focused on teaching than research. Some universities are likely to focus on their strengths in order to attract fee-paying students, leading to specialization in some parts of the sector. This is desirable: in a country with a limited population and resources, the idea of all universities trying to be all things to all people is hopelessly idealistic.

An egregious omission from the reform package is any mention of further infrastructure support for universities, many of which have to use teaching money to support their research, as Australian grants rarely cover overheads. The government must redress this when it completes its ongoing audit of the nation's scientific landscape.

But is further exposing the universities to market forces the best way of obtaining excellence? For a nation hoping to benefit economically and socially from the fruits of world-class university research and teaching, more substantial government investment would have been appropriate. Driving universities to compete for fee-paying students runs the risk of reshaping universities as sites of vocational training rather than as places of higher learning. Without striking the right balance between public funding and student contributions, the Australian government may severely blunt the leading edge, both in education and research, that its best universities represent.

\section{Recovering from cultural devastation}

\section{Leaders of the world's scientific community must act with more speed and determination to help reconstruct Iraq.}

n central Baghdad, Iraq's National Library and National Archives lie ransacked and burnt to the ground, under the noses of coalition troops. The Bush administration's disrespect for a basic precept of the prosecution of war - the preservation of cultural heritage — has led to the unnecessary loss of much of the record of 10,000 years of history. Baghdad's Iraqi National Museum, the world's finest collection on earliest human civilization, has been plundered. So too have its universities (see page 468).

Military schools will no doubt teach that the United States' technological superiority in battle significantly reduced 'collateral damage' in terms of civilian lives. They might also discuss the 1954 Hague Convention for the Protection of Cultural Property in the Event of Armed Conflict, which the United States has not ratified.

With lives being lost, why should one care about science and culture? Because wars end, and shattered lives, communities and societies must be rebuilt. Amid the pressing humanitarian needs, the international community must help to reconstruct the training of the next generation to lead Iraq. The immediate priority is to put the universities back on their feet. International scientific collaboration must then use the full 'shock and awe' of civilian science and technology to protect public health, secure water resources, and rebuild infrastructure and the economy. So far, the international community has been mute in this regard, and the United Nations agency charged with science, UNESCO, has been slow and ineffective.

That must change, and fast. The top priority is to establish the state of infrastructure and the most pressing needs. A conference, perhaps under the auspices of UNESCO, could bring together Iraqi scientists and outside organizations. At the same time, individual scientists and their institutions can reach out to their counterparts in Iraq.

The Bush leadership intends to purge science of Ba'ath Party members, but it should remember that despite widespread nepotism at senior levels, allegiance was often token. Many decent scientists who can help to rebuild Iraq were Ba'ath Party members out of pragmatism. They must be recruited for the reconstruction that lies ahead. 